\title{
ACUTE TOXICITY OF WATER SOLUBLE, INSOLUBLE AND WHOLE CRUDE FRACTIONS (BONNY LIGHT) ON THE EARLY LIFE STAGES OF HOPLOBATRACHUS OCCIPITALIS (CROWNED BULL FROG) IN CALABAR, NIGERIA
}

\author{
${ }^{* 1}$ Mowang, A. D., ${ }^{2}$ Naku, U. J., ${ }^{3}$ Ndome, B. C. and ${ }^{4}$ Ayim, M. E.
}

\author{
${ }^{* 1,3,4}$ Department of Zoology and Environmental Biology, University of Calabar, Nigeria. \\ ${ }^{*}$ Phone: +2348030746060 Email: dominicmowang@yahoo.com \\ ${ }^{2}$ Department of General Studies, College of Health Technology, Calabar, Nigeria. \\ 2Phone: +2347030593536 Email: nakujul@yahoo.com \\ ${ }^{3}$ Phone: +2348034066475 Email: cndome@yahoo.com \\ ${ }^{4}$ Phone: +234803971363658 Email: ayimmonfung@yahoo.com
}

\begin{abstract}
This study examined the effect of different concentrations of bonny light crude oil on the development and growth of the tadpoles of the crowned bullfrogs. After series of range finding tests (RFT) the tadpoles of $H$. occipitalis were exposed to acute and sub-lethal log concentrations of 0.00 ppm, 1.00 ppm, 1.30 ppm, 1.48 ppm, 1.60 ppm, 1.65 ppm and1.69 ppm of different fractions of bonny light crude for 96 hours. The various fractions of crude recorded no significant differences in mortalities $(\mathrm{P}>0.05)$ for three- and four-weeks old tadpoles. The mortalities increased with increase in concentration of toxicants. The tadpoles recorded 75\% mortalities in Water Soluble Fraction (WSF), $65 \%$ mortalities in Water Insoluble Fraction (WIF) and $70 \%$ and $75 \%$ mortalities respectively in Whole Crude (WC). The WSF of crude showed the lowest $\mathrm{LC}_{50}$ 's in the tadpoles ranging from $1.51 \pm 0.17 \mathrm{ppm}$ with (lower limit 1.45 and upper limit 1.55 ) to $1.61 \pm 0.37$ ppm with (lower limit 1.58 and upper limit 1.65). WIF showed the highest LC 50 's in the tadpoles ranging from $1.62 \pm 0.42$ with (lower limit 1.59 and upper limit 1.66) to $1.69 \pm 0.41 \mathrm{ppm}$ with (lower limit 1.55 and upper limit 1.62). The WC showed an $\mathrm{LC}_{50}$ 's range of $1.60 \pm 0.37$ ppm with (lower limit 1.56 and upper limit 1.64) to $1.63 \pm 0.32 \mathrm{ppm}$ with (lower limit 1.59 and upper limit 1.66). Results shows that increased toxicity produced higher mortalities in tadpoles of $H$. occipitalis (an endangered species). This study therefore advocates that Oil companies should adhere to the current WHO / FEPA regulatory limits of $0.2 \mathrm{mg} / \mathrm{l}$ to $14.0 \mathrm{mg} / \mathrm{l}$ for $\mathrm{C}_{5}-\mathrm{C}_{22}$ hydrocarbons to ensure the survival of its vital ecological niche.
\end{abstract}

Keywords: water soluble fraction (WSF), water insoluble fraction (WIF), whole crude (WC), Hoblobatrachus occipitalis

LICENSE: This work by Open Journals Nigeria is licensed and published under the Creative Commons Attribution License 4.0 International License, which permits unrestricted use, distribution, and reproduction in any medium, provided this article is duly cited.

COPYRIGHT: The Author(s) completely retain the copyright of this published article.

OPEN ACCESS: The Author(s) approves that this article remains permanently online in the open access (OA) mode.

QA: This Article is published in line with "COPE (Committee on Publication Ethics) and PIE (Publication Integrity \& Ethics)". 


\section{INTRODUCTION}

The introduction of crude oil (petroleum) can be very fatal to a population of amphibians including eggs and larval forms (tadpoles) directly or indirectly. Crude oil suppresses the immune system allowing subsequent infection by opportunistic pathogens. Population size could be reduced by reproductive impairment. Reproduction could be impaired by environmental interference. This could occur in adult reproductive function, inhibiting breeding behaviour, gamete formation, or fertilization. This could result in the disruption of development and growth of the young. There are evidence of chemical pollutants causing frog developmental deformities (such as extra limbs and malformed eyes) (Blaustein et al., 2003; Burkhart et al., 2002). Crude oil pollutants have varying effects on frogs. Some alter the central nervous system, others like atrazine cause a disruption in the production and secretion of hormones. Experimental studies have also shown that exposure to commonly used herbicides such as glyphosate (Round up) or insecticides such as malathion or carbaryl greatly increase mortality of tadpoles (Relyea, 2004). Mowang et al. (2015) reported toxicity of Water soluble, Water insoluble fractions and Whole crude on one- and twoweeks old tadpoles of $H$. occipitalis. Additional studies have indicated that terrestrial adult stages of amphibians are also susceptible to non-active ingredients in round up, particularly Polyoxyethylene tallow amine (POEA), which is a surfactant (Relyea, 2005). In a study conducted in a laboratory at Upsala University in Sweden, more than 50\% of frogs exposed to various levels of estrogen-like pollutants existing in natural bodies of water in Europe and the United States became females. A study by Ezemonye and Ewuneku (2005) on the acute toxicity of cadmium to tadpoles of Bufo maculatus and Ptychaden bibroni, revealed that acute toxicity of cadmium to both species was species specific. Tadpoles of Bufo maculatus appeared to be good bio-indicators of cadmium owing to their high tolerance level. This study suggested that anuran larvae are very sensitive to anthropogenic stressors containing heavy metals. Another study by Enyamremu et al., (2007) was on the effect of sub-lethal levels of bonny light crude oil and its water soluble and insoluble fractions on stress enzymes in tadpoles (xenopus laevis) following two- and four-weeks exposure at different concentrations. Mahaney (1994) found that while hatching success of Hyla cinerea eggs was not significantly impacted by exposure to 10,55 and $100 \mathrm{mg} / \mathrm{\iota}$ of crankcase oil, growth rates of larvae exposed to higher concentrations of oil were significantly retarded

It is apparent that the activity of crude oil exploration has impacted largely on the aquatic ecosystem affecting both aquatic flora and fauna. In Southern Nigeria, the Hoplobatrachus occipitalis frogs are gradually reducing probably due to oil exploration in the Niger Delta. While some information exists on the toxicity of crude oil and some metals on amphibians, very little work has been done on local African species. Because of the differences in sensitivity and concern about crude oil and metal contaminants, it is imperative to conduct acute toxicity tests of crude oil on local frog species to enable us ascertain the deleterious effects of certain concentrations of crude oil on amphibians during any part of their life cycle. Evaluating the stage dependent acute toxicity of crude oil to tadpoles of Hoplobatrachus occipitalis is an effort aimed at preventing amphibian declines in the Niger Delta. This study will help to proffer some solution to the alarming rate of amphibian decline in the world. It will also help the oil companies to be more serious about preventing oil spills and help provide basic information needed by future researchers in this field. 
This research was aimed at determining the rates of mortality of three and four weeks old tadpoles, manifestation time and survival time of H.occipitalis treated with different concentrations of WSF, WIF and WC fractions of bonny light crude and to estimate the $\mathrm{LC}_{50}$ of exposure after $96 \mathrm{~h}$ of crude on three and four weeks old tadpoles of $H$. occipitalis.

\section{MATERIALS AND METHODS}

\section{DESCRIPTION OF THE STUDY AREA}

\section{LOCATION}

The experimental animals were collected from ponds in Calabar, the State capital of Cross River State Nigeria. Calabar lies on lat. $4^{\circ} 57^{\prime} \mathrm{N}$ and Longitude $8^{\circ} 19^{\prime} \mathrm{E}$.

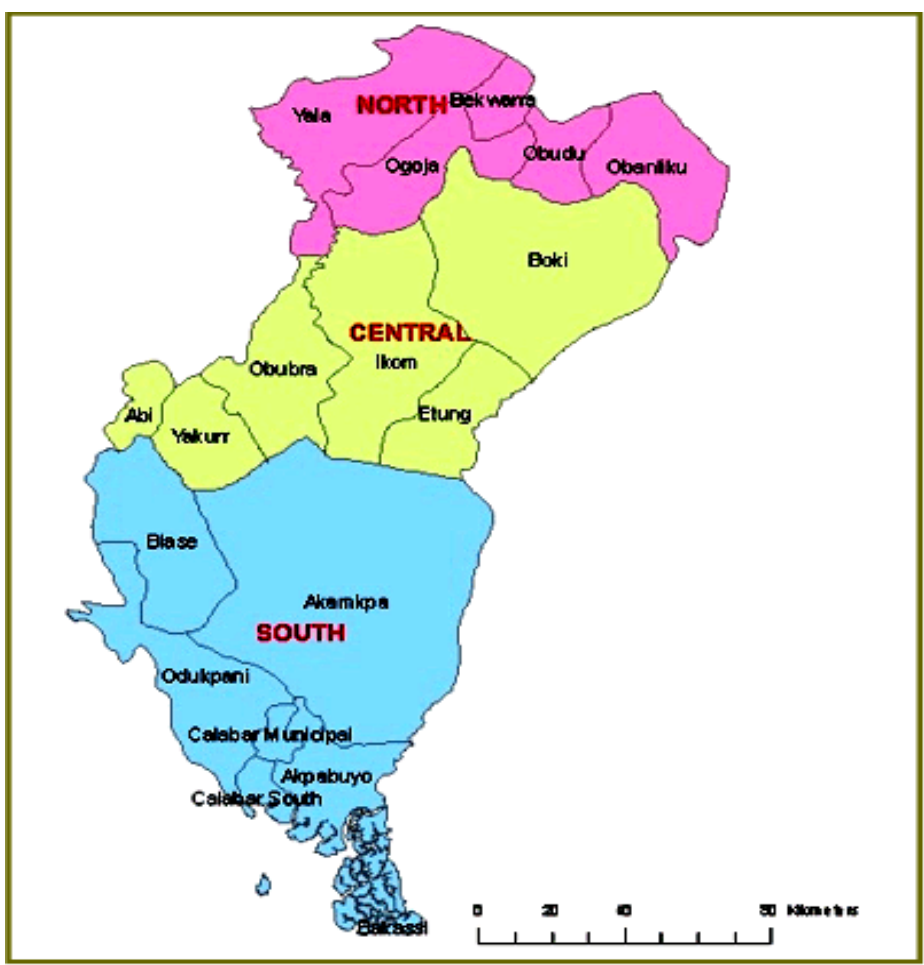

Figure 1: Map of Cross River state showing the study area encircled.

Source: Cross River State geographical Survey.

\section{COLLECTION AND TRANSPORTATION OF THE EXPERIMENTAL ANIMAL}

Six sexually mature frogs (Hoplobatrachus occipitalis), 3 males with pronounced vocal sacs and a dark bluish-black nuptial pads, (swellings) on their first fingers as their secondary sexual characters and 3 females (larger in size than males and with orange/white underside as their secondary characters) of Hoplobatrachus occipitalis were collected with a long handled scoop net from stagnant old ponds within University of Calabar farm. The experimental animals were transported in plastic buckets in the late hours of the evening between 6-7 pm, to reduce heat shock during 
transportation to the Research Laboratory of the Department of Zoology and Environmental Biology, University of Calabar, where they were cultured till the eggs were laid and hatched to tadpoles (Plates 1, 2 and 3).

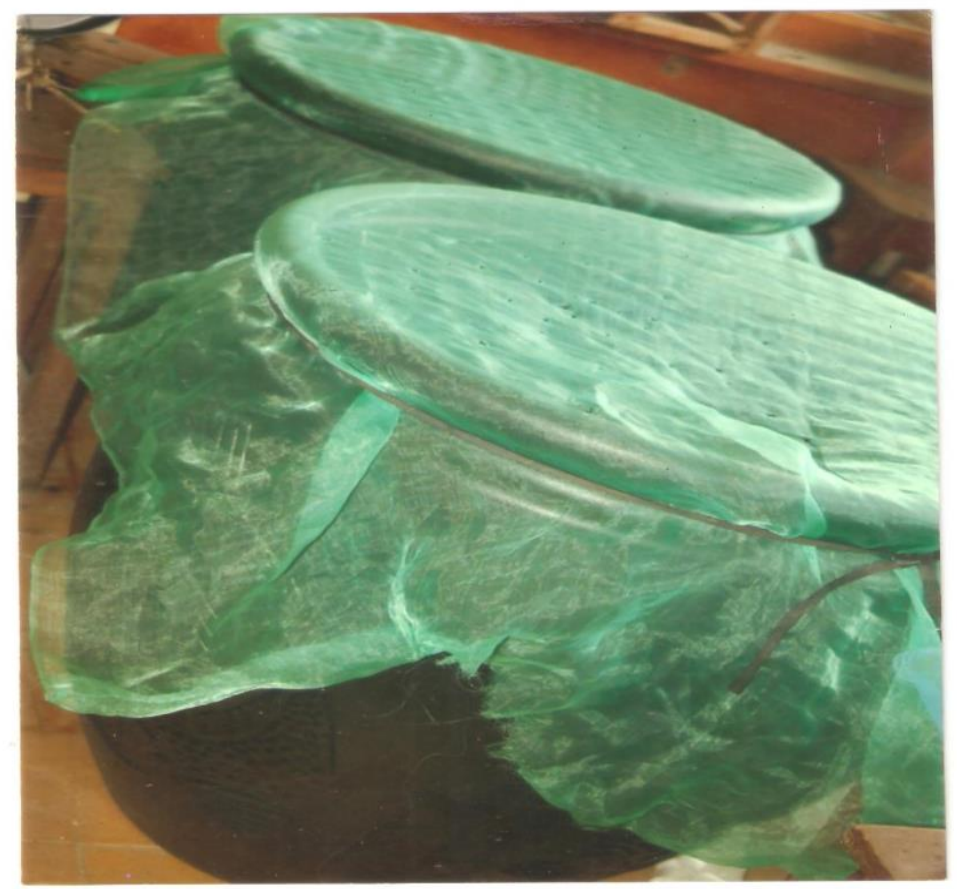

Plate 1: Culturing pot for Hoplobatrachus occipitalis

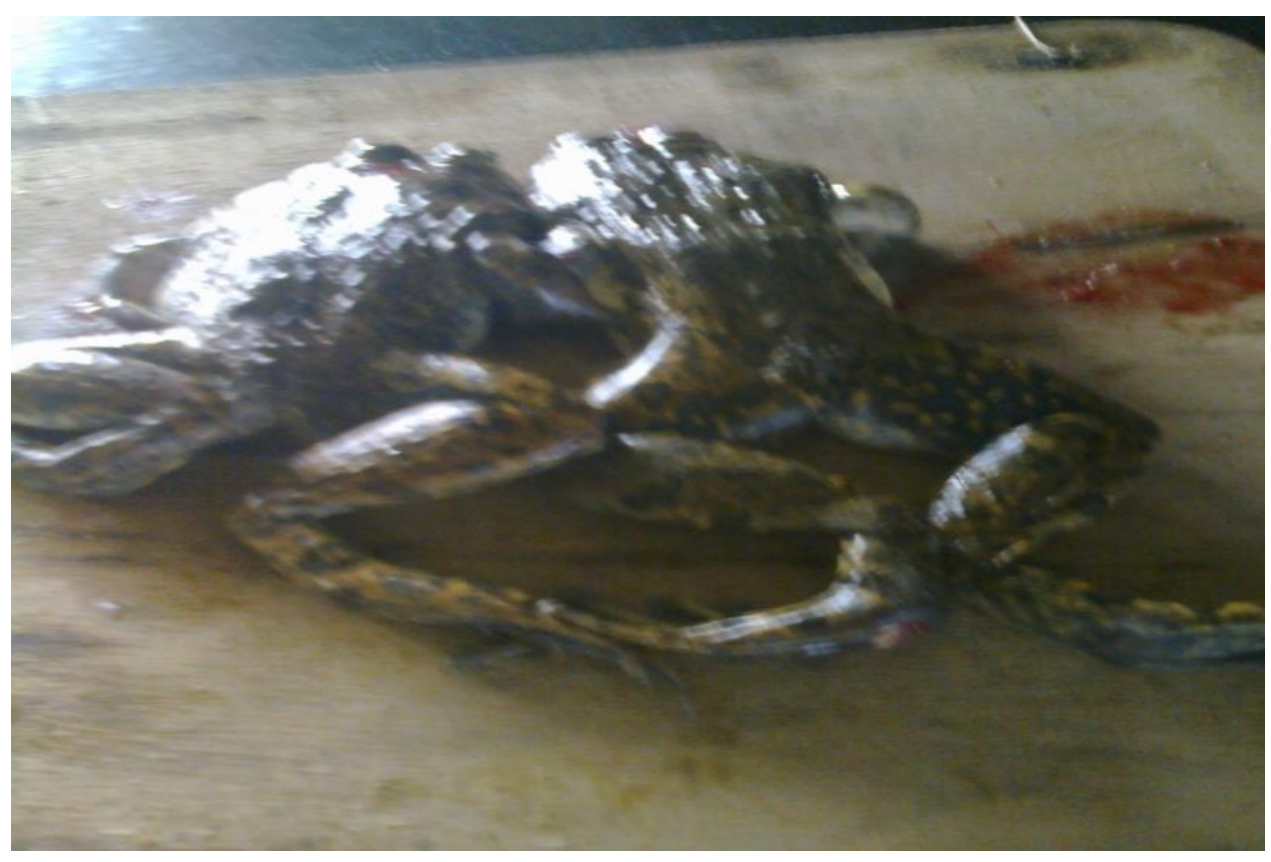

Plate 2: Hoplobatrachus occipitalis adults (Gunther,1858) 


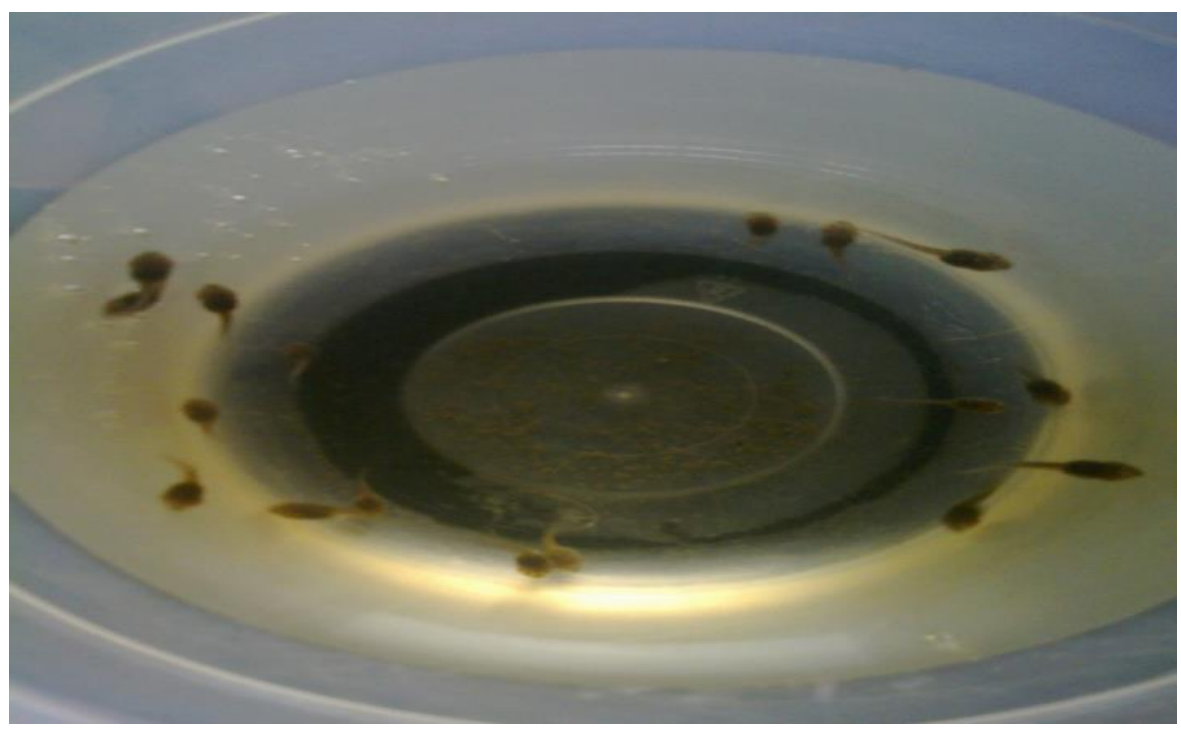

Plate 3: Hatched tadpoles of H. occipitalis in the Department of Zoology and Environmental Biology Laboratory University of Calabar.

\section{PROCEDURE FOR THE FRACTIONATION OF THE CRUDE OIL INTO WATER SOLUBLE (WSF) AND INSOLUBLE COMPONENTS (WIF).}

This procedure was carried out in the department of pure and applied Chemistry University of Calabar, Calabar. The $250 \mathrm{~cm}^{3}$ of crude oil sample was measured with $250 \mathrm{~cm}^{3}$ measuring cylinder and poured into the round bottom flask that was connected to the soxhlet extractor then two (2) pellets of anti-pumping granules were added to the flask content and placed on the heating mantle before connecting to the heating source. The inlet and outlet tubing's from the condenser were connected to the running water tap to cool the system. The mains were then switched on for continuous extraction until the soluble extract was obtained. Solvent extraction was used for the extraction of the soluble components in methanol and Dichloromethane extract respectively. The soluble extraction was then concentrated by distilling out both the methanol and the Dichloromethane for the soluble extract. The concentrate was used as soluble extract and the residue as insoluble extract.

\section{TOXICITY TESTS}

Toxicity tests were conducted in 36 rectangular glass aquaria measuring $15 \mathrm{~cm}$ x $30 \times 15 \mathrm{~cm}$ cubic capacity $3 / 4$ filled with well aerated tap water according to Dede and Kagbo (2001). The tadpoles of Hoplobatrachus occipitalis at specific post-hatch maturation stages ( 3 and 4 weeks) were also assigned to a control group of 20 and three other test groups of 20 each. Each test group was treated with either whole crude (WC) or water-soluble fraction (WSF) or water insoluble fraction (WIF). Each of these groups was treated with log concentrations $0.00 \mathrm{ppm}, 1.00 \mathrm{ppm}, 1.30 \mathrm{ppm}$, $1.48 \mathrm{ppm}, 1.60 \mathrm{ppm}, 1.65 \mathrm{ppm}$ and $1.69 \mathrm{ppm}$. Tadpoles were considered dead when they became immobile, ceased all respiratory movements (Mgbeahuru, 2002) and failed to respond to a slight prod with a rod. They were also taken to be dead when they turned upside down or floated (Neghenebor, 2002). The effects of the various concentrations of 
the water-soluble fraction, water insoluble fraction and whole crude on the tadpoles of $\mathrm{H}$. occipitalis were monitored on a three (3) hours basis whereas the mortality was measured on a 12 hours basis for 96 hours.

\section{DETERMINATION OF MORTALITY RATES OF TADPOLES.}

The percentage mortality rates of the eggs and tadpoles in the different concentrations of the WSF, WIF and WC during the period of study was determined using the formula: $\%$ mortality $=\mathrm{n} / \mathrm{N} \mathrm{X} 100$, Where: $\mathrm{n}=$ number of dead individuals per tank, per concentration, $\mathrm{N}=$ Total number of organism stocked (Udo et al., 2006).

\section{STATISTICAL ANALYSIS}

The mortality data were subjected to probit transformation and analysis using Statistical package for social sciences (SPSS 18.0) and the $\mathrm{Lc}_{50}$ values computed. The $95 \%$ confidence limits were also form. The significance of the slope was tested using ANOVA and Duncan testes.

\section{RESULTS}

\section{MORTALITY, SURVIVOR, MANIFESTATION TIME AND SURVIVAL TIME OF THREE WEEKS AND FOUR WEEKS OLD TADPOLES EXPOSED TO DIFFERENT FRACTIONS OF CRUDE PETROLEUM.}

Behavioral changes such as reduced swimming performance, reduced length of tadpoles, fluid filled blisters on the body and tail, incessant jumping and gulping of air, restlessness, frequent surface to bottom movement, sudden directional changes during movement loss of equilibrium and gradual onset of inactivity and change in slain colouration were observed.

The three weeks old tadpoles in WSF recorded mean mortalities of $0 \pm 6.73$ in $1.00 \mathrm{ppm}, 3 \pm 5.74$ in $1.30 \mathrm{ppm}$, $7 \pm 4.60$ in $1.48 \mathrm{ppm}, 10 \pm 3.77$ in $1.60 \mathrm{ppm}, 13 \pm 3.06$ in $1.65 \mathrm{ppm}, 15 \pm 2.83$ in $1.69 \mathrm{ppm}$ and percentage mortalities of $0 \%$ in $1.0 \mathrm{ppm}, 15 \%$ in $1.30 \mathrm{ppm}, 35 \%$ in $1.48 \mathrm{ppm}, 50 \%$ in $1.60 \mathrm{ppm}, 65 \%$ in $1.65 \mathrm{ppm}$ and $75 \%$ in $1.69 \mathrm{ppm}$ (Table 1 ). The percentage survivors in the three weeks old tadpoles were also $100 \%$ in the control and in the $1.00 \mathrm{ppm}, 85 \%$ in $1.30 \mathrm{ppm}, 70 \%$ in $1.48 \mathrm{ppm}, 50 \%$ in $1.60 \mathrm{ppm}, 35 \%$ in $1.65 \mathrm{ppm}$ and $25 \%$ in $1.69 \mathrm{ppm}$ in the WSF (Table 1). The manifestation time in WSF ranges from 0 in control to $19 \mathrm{~h}$ in 1.69ppm (Table 1). The survival time in WSF ranges from $96 \mathrm{~h}$ to $17 \mathrm{~h}$ in $1.69 \mathrm{ppm}$ (Table 1 ). 
Table 1: Mortality, Survivor, Manifestation time and Survival time of three weeks old tadpoles exposed to WSF of crude petroleum.

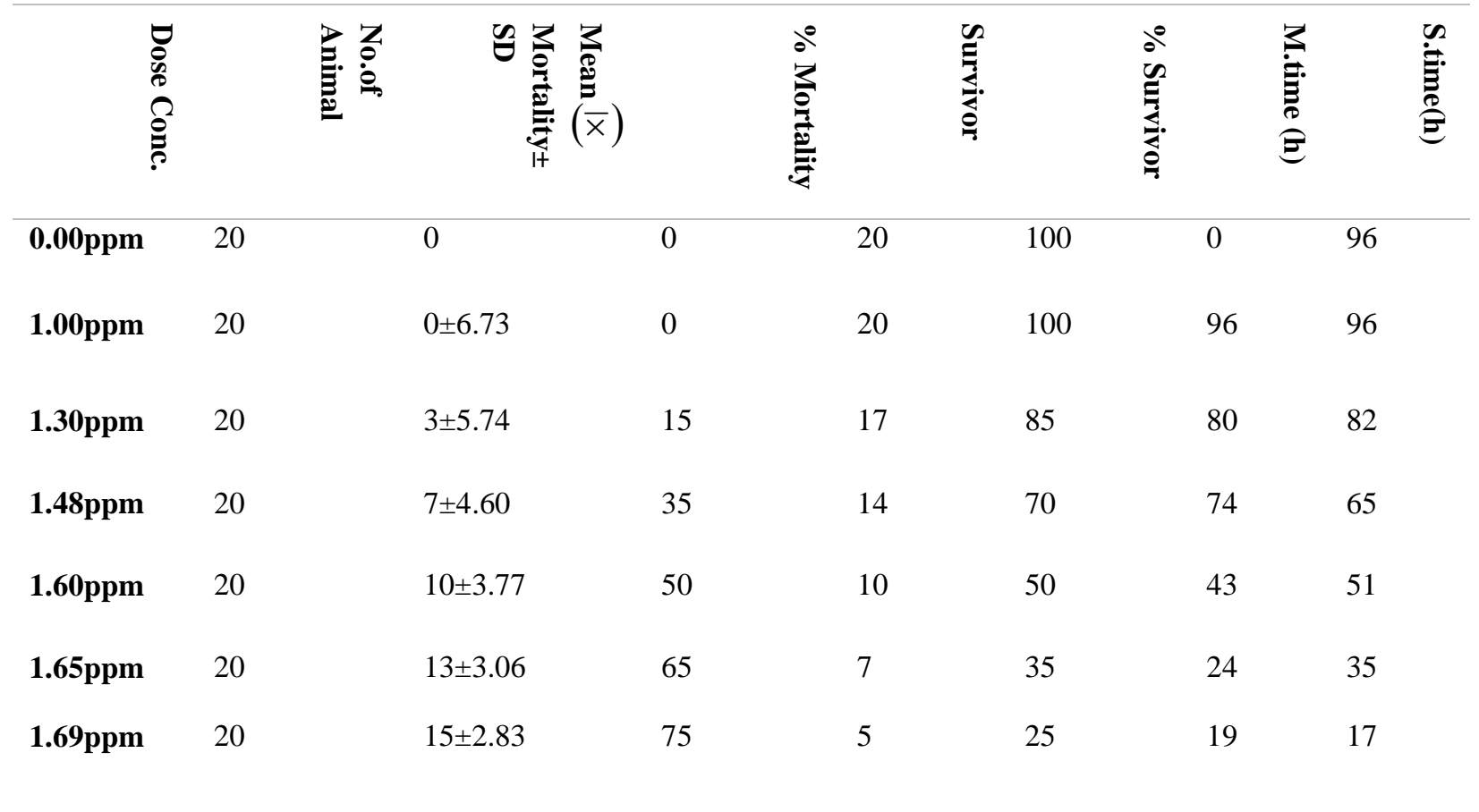

SD-standard deviation, M.time-Manifestation time, S.time-survival time,

WSF-Water Soluble Fraction.

The WIF recorded mean mortalities of $0 \pm 6.36$ in $1.00 \mathrm{ppm}, 2 \pm 5.75$ in $1.30 \mathrm{ppm}, 5 \pm 4.95$ in $1.48 \mathrm{ppm}, 8 \pm 4.20$ in $1.60 \mathrm{ppm}$, $11 \pm 3.61$ in $1.65 \mathrm{ppm}, 13 \pm 3.54$ in $1.69 \mathrm{ppm}$ and percentage mortalities of $0 \%$ in $1.00 \mathrm{ppm}, 10 \%$ in $1.30 \mathrm{ppm}, 25 \%$ in $1.48 \mathrm{ppm}, 40 \%$ in $1.60 \mathrm{ppm}, 55 \%$ in $1.65 \mathrm{ppm}$ and $65 \%$ in $1.69 \mathrm{ppm}$ (Table 2). While the WIF recorded percentage survivor of $100 \%$ in the control and in the $1.00 \mathrm{ppm}, 90 \%$ in $1.30 \mathrm{ppm}, 75 \%$ in $1.48 \mathrm{ppm}, 60 \%$ in $1.60 \mathrm{ppm}, 45 \%$ in $1.65 \mathrm{ppm}$ and $35 \%$ in $1.69 \mathrm{ppm}$ (Table 2). The manifestation and survival times in WIF ranges from $0-23 \mathrm{~h}$ and $96-$ $24 \mathrm{~h}$ in the control to $1.69 \mathrm{ppm}$ respectively (Table 2 ). 
Table 2: Mortality, Survivor, Manifestation time and Survival time of three weeks old tadpoles exposed to WIF of crude petroleum.

\begin{tabular}{|c|c|c|c|c|c|c|c|}
\hline$\theta$ & $\begin{array}{l}Z \\
\stackrel{2}{0} \\
\stackrel{0}{\dot{\theta}}\end{array}$ & 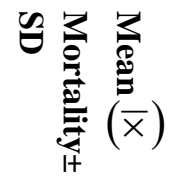 & 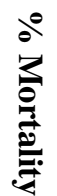 & 岂 & $\begin{array}{l}d^{9} \\
0 \\
\vdots \\
\vdots \\
\vdots \\
0 \\
0\end{array}$ & 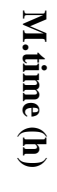 & 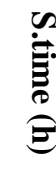 \\
\hline
\end{tabular}

\begin{tabular}{|c|c|c|c|c|c|c|c|}
\hline 0.00ppm & 20 & 0 & 0 & 20 & 100 & 0 & 96 \\
\hline 1.00ppm & 20 & $0 \pm 6.36$ & 0 & 20 & 100 & 96 & 96 \\
\hline 1.30ppm & 20 & $2 \pm 5.75$ & 10 & 18 & 90 & 81 & 86 \\
\hline 1.48ppm & 20 & $5 \pm 4.95$ & 25 & 15 & 75 & 69 & 77 \\
\hline $1.60 \mathrm{ppm}$ & 20 & $8 \pm 4.20$ & 40 & 12 & 60 & 43 & 53 \\
\hline 1.65ppm & 20 & $11 \pm 3.61$ & 55 & 9 & 45 & 27 & 33 \\
\hline 1.69ppm & 20 & $13 \pm 3.54$ & 65 & 7 & 35 & 23 & 24 \\
\hline
\end{tabular}

SD-standard deviation, M.time-Manifestation time,S.time-survival time,

WIF-Water insoluble Fraction.

The mean mortalities in WC were $0 \pm 6.58$ in $1.00 \mathrm{ppm}, 3 \pm 5.75$ in $1.30 \mathrm{ppm}, 6 \pm 4.95$ in $1.48 \mathrm{ppm}, 9 \pm 4.20$ in $1.60 \mathrm{ppm}, 12 \pm 3.61$ in $1.65 \mathrm{ppm}, 14 \pm 3.54$ in $1.69 \mathrm{ppm}$ and percentage mortalities of $0 \%$ in $1.00 \mathrm{ppm}, 15 \%$ in $1.30 \mathrm{ppm}$, $30 \%$ in $1.48 \mathrm{ppm}, 45 \%$ in $1.60 \mathrm{ppm}, 60 \%$ in $1.65 \mathrm{ppm}$ and $70 \%$ in $1.69 \mathrm{ppm}$ respectively. (Table 3 ). The WC recorded percentage survivor of $100 \%$ in the control and in the $1.00 \mathrm{ppm}, 85 \%$ in $1.30 \mathrm{ppm}, 70 \%$ in $1.48 \mathrm{ppm}, 55 \%$ in $1.60 \mathrm{ppm}$, $40 \%$ in $1.65 \mathrm{ppm}$ and $35 \%$ in $1.69 \mathrm{ppm}$ (Table 3). The manifestation and survival times in WC ranges from 0Hrs in control to $18 \mathrm{Hrs}$ in $1.69 \mathrm{ppm}$. While the survival time of $96 \mathrm{Hrs}$ in $0.00 \mathrm{ppm}$ to $16 \mathrm{Hrs}$ in $1.69 \mathrm{ppm}$ were also recorded in WC (Table 3). 
Table 3: Mortality, Survivor, Manifestation time and Survival time of three weeks old tadpoles exposed to WC of crude petroleum.

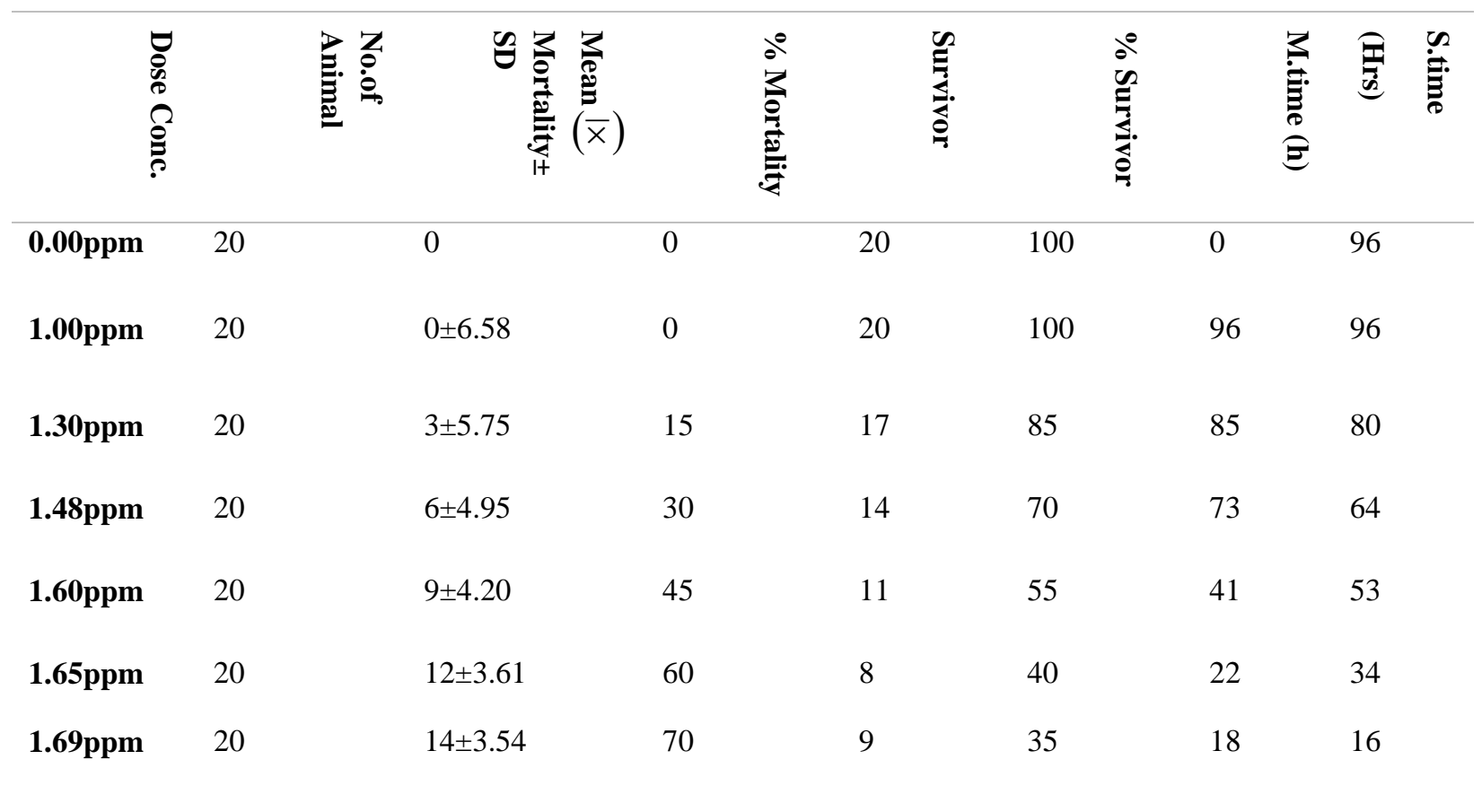

SD-standard deviation,M.time-Manifestation time,S.time-survival time,

WC-Whole crude.

In the same vein, the four weeks old tadpoles in WSF recorded mean mortalities of $0 \pm 7.20$ in $1.00 \mathrm{ppm}, 2 \pm 6.49$ in $1.30 \mathrm{ppm}, 6 \pm 5.41$ in $1.48 \mathrm{ppm}, 9 \pm 4.57$ in $1.60 \mathrm{ppm}, 13 \pm 3.61$ in $1.65 \mathrm{ppm}, 15 \pm 3.54$ in $1.69 \mathrm{ppm}$ and percentage mortalities of $0 \%$ in $1.0 \mathrm{ppm}, 10 \%$ in $1.30 \mathrm{ppm}, 30 \%$ in $1.48 \mathrm{ppm}, 45 \%$ in $1.60 \mathrm{ppm}, 65 \%$ in $1.65 \mathrm{ppm}$ and $75 \%$ in 1.69ppm (Table 4). The percentage survivors in the four weeks old tadpoles were also $100 \%$ in the control and $1.00 \mathrm{ppm}, 90 \%$ in $1.30 \mathrm{ppm}, 70 \%$ in $1.48 \mathrm{ppm}, 55 \%$ in $1.60 \mathrm{ppm}$ in the WSF (Table 4). The manifestation and survival times of four weeks old tadpoles exposed to WSF of crude ranges from 0 - 18Hrs and 96 - 16Hrs respectively (Table 4). 
Table 4: Mortality, Survivor, Manifestation time and Survival time of four weeks old tadpoles exposed to WSF of crude petroleum.

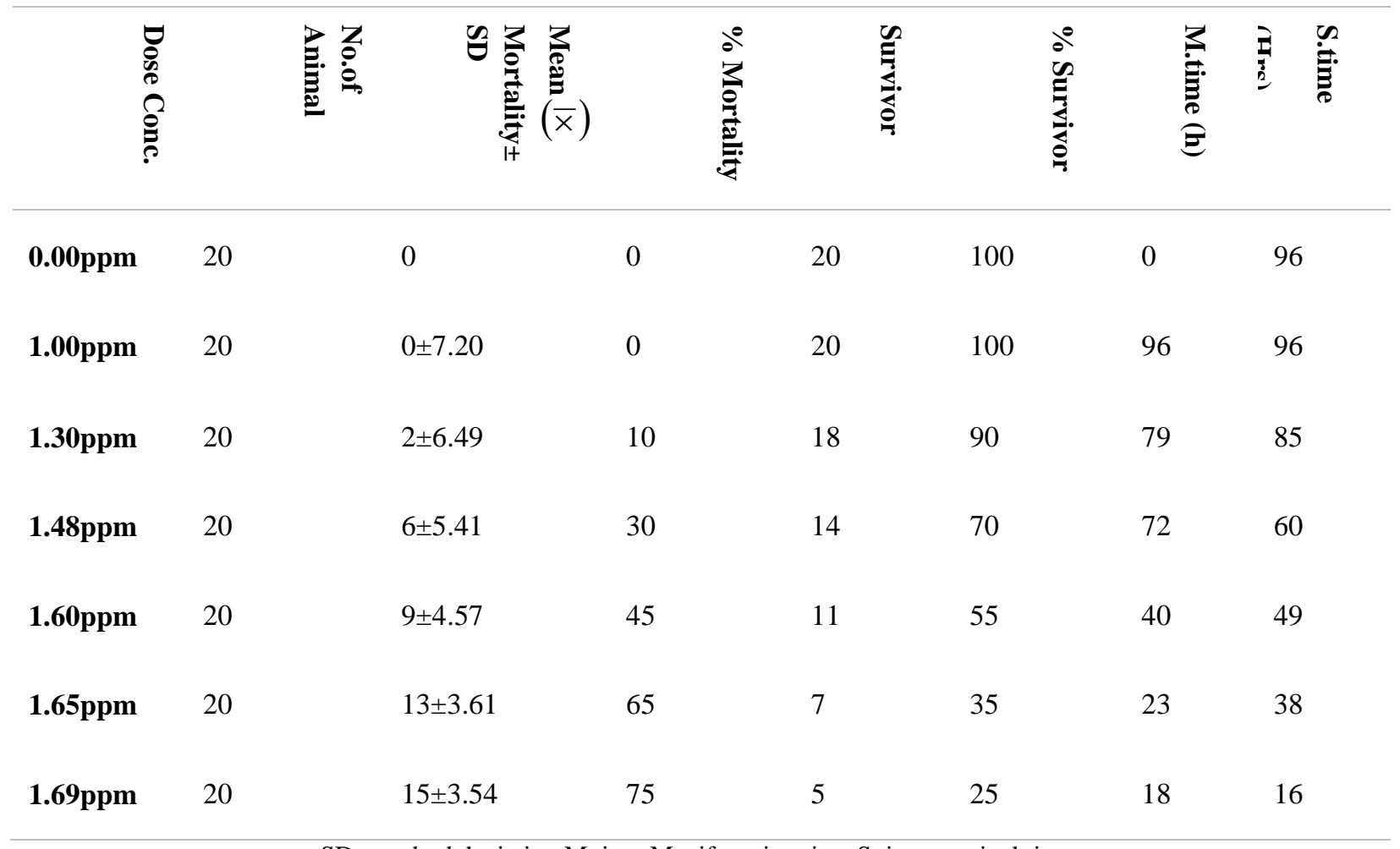

SD-standard deviation,M.time-Manifestation time,S.time-survival time,

WSF-Water Soluble Fraction.

WIF recorded mean mortalities of $0 \pm 6.58$ in $1.0 \mathrm{ppm}, 2 \pm 6.09$ in $1.30 \mathrm{ppm}, 5 \pm 5.50$ in $1.48 \mathrm{ppm}, 7 \pm 5.12$ in $1.60 \mathrm{ppm}$, $10 \pm 4.58$ in $1.65 \mathrm{ppm}, 13 \pm 4.24$ in $1.69 \mathrm{ppm}$ and percentage mortalities of $0 \%$ in $1.00 \mathrm{ppm}, 10 \%$ in $1.30 \mathrm{ppm}, 25 \%$ in $1.48 \mathrm{ppm}, 35 \%$ in $1.60 \mathrm{ppm}, 50 \%$ in $1.65 \mathrm{ppm}$ and $65 \%$ in $1.69 \mathrm{ppm}$ respectively (Table 5). The WIF recorded percentage survivors of $100 \%$ in the control and in $1.00 \mathrm{ppm}, 90 \%$ in $1.30 \mathrm{ppm}, 75 \%$ in $1.48 \mathrm{ppm}, 70 \%$ in $1.60 \mathrm{ppm}$, $50 \%$ in $1.65 \mathrm{ppm}$ and $35 \%$ in $1.69 \mathrm{ppm}$ (Table 5). In the same vein, the manifestation and survival times in WIF ranged from $0-22 \mathrm{Hrs}$ and $96-21 \mathrm{Hrs}$ respectively (Table 5). 
Table 5: Mortality, Survivor, Manifestation time and Survival time of four weeks old tadpoles exposed to WIF of crude petroleum.

\begin{tabular}{|c|c|c|c|c|c|c|c|c|c|}
\hline $\begin{array}{l}0 \\
0 \\
0 \\
0 \\
0 \\
0\end{array}$ & & 超? & 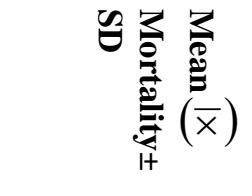 & $\sum^{3} a^{9}$ & $\stackrel{\mathscr{E}}{\vdots}$ & & $\begin{array}{l}09 \\
0 \\
\vdots \\
\vdots \\
\vdots \\
0 \\
0\end{array}$ & 光 & $\stackrel{y}{\bar{b}}$ \\
\hline $0.00 \mathrm{ppm}$ & 20 & & 0 & 0 & 20 & 100 & & 0 & 96 \\
\hline 1.00ppm & 20 & & $0 \pm 6.58$ & 0 & 20 & 100 & & 96 & 96 \\
\hline $1.30 \mathrm{ppm}$ & 20 & & $2 \pm 6.09$ & 10 & 18 & 90 & & 88 & 84 \\
\hline 1.48ppm & 20 & & $5 \pm 5.50$ & 25 & 15 & 75 & & 75 & 62 \\
\hline $1.60 \mathrm{ppm}$ & 20 & & $7 \pm 5.12$ & 35 & 14 & 70 & & 52 & 51 \\
\hline $1.65 p p m$ & 20 & & $10 \pm 4.58$ & 50 & 10 & 50 & & 26 & 33 \\
\hline $1.69 \mathrm{ppm}$ & 20 & & $13 \pm 4.24$ & 65 & 7 & 35 & & 22 & 21 \\
\hline
\end{tabular}

SD-standard deviation,M.time-Manifestation time,S.time-survival time, WIF-Water insoluble Fraction.

The WC recorded mean mortalities of $0 \pm 6.72$ in $1.00 \mathrm{ppm}, 3 \pm 5.89$ in $1.30 \mathrm{ppm}, 6 \pm 5.07$ in $1.48 \mathrm{ppm}, 9 \pm 4.27$ in $1.60 \mathrm{ppm}, 12 \pm 3.51$ in $1.65 \mathrm{ppm}, 15 \pm 2.83$ in $1.69 \mathrm{ppm}$ and its percentage mortalities was recorded at $0 \%$ in $1.00 \mathrm{ppm}$, $15 \%$ in $1.30 \mathrm{ppm}, 30 \%$ in $1.48 \mathrm{ppm}, 45 \%$ in $1.60 \mathrm{ppm}, 60 \%$ in $1.65 \mathrm{ppm}$ and $75 \%$ in $1.69 \mathrm{ppm}$ (Table 6 ). The WC recorded percentage survivor of $100 \%$ in the control and in $1.00 \mathrm{ppm}, 85 \%$ in $1.30 \mathrm{ppm}, 70 \%$ in $1.48 \mathrm{ppm}, 55 \%$ in $1.60 \mathrm{ppm}, 40 \%$ in $1.65 \mathrm{ppm}$ and $25 \%$ in $1.69 \mathrm{ppm}$ (Table 6). The manifestation time and survival time of four weeks old tadpoles exposed to WC of crude petroleum ranged from 0 - 17 Hrs and 96 - 16Hrs respectively (Table 6). 
Table 6: Mortality, Survivor, Manifestation time and Survival time of four weeks old tadpoles exposed to WC of

20 | Mowang et al., 2020
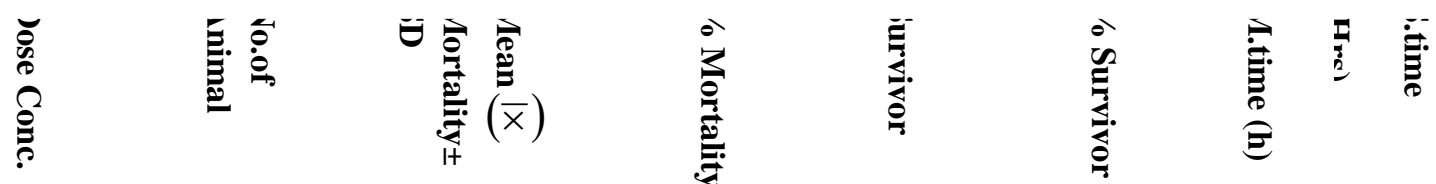

$\begin{array}{llllcccc}\mathbf{0 . 0 0 p p m} & 20 & 0 & 0 & 20 & 100 & 0 & 96 \\ \mathbf{1 . 0 0 p p m} & 20 & 0 \pm 6.72 & 0 & 20 & 100 & 96 & 96 \\ \mathbf{1 . 3 0 p p m} & 20 & 3 \pm 5.89 & 15 & 17 & 85 & 83 & 82 \\ \mathbf{1 . 4 8} p \mathbf{p m} & 20 & 6 \pm 5.07 & 30 & 14 & 70 & 74 & 59 \\ \mathbf{1 . 6 0 p p m} & 20 & 9 \pm 4.27 & 45 & 11 & 55 & 40 & 47 \\ \mathbf{1 . 6 5 p p m} & 20 & 12 \pm 3.51 & 60 & 8 & 40 & 21 & 36 \\ \mathbf{1 . 6 9 p p m} & 20 & 15 \pm 2.83 & 75 & 5 & 25 & 17 & 16\end{array}$

SD-standard deviation,M.time-Manifestation time,S.time-survival time,

WC-Whole Crude.

\section{MEAN LC50 AT 95\% CONFIDENCE LIMIT OF 3- AND 4-WEEKS OLD TADPOLES EXPOSED TO DIFFERENT FRACTIONS OF CRUDE PETROLEUM.}

The $\mathrm{LC}_{50}$ at $95 \%$ confidence limits of three weeks old tadpoles exposed to WSF, WIF and WC were determined as1.60 $\pm 0.32 \mathrm{WSF}, 1.65 \pm 0.39 \mathrm{WIF}$ and $1.63 \pm 0.28 \mathrm{WC}$ giving an $\mathrm{LC}_{50}$ intervals of 1.57 to $1.64 \mathrm{WSF}, 1.62$ to 1.68 WIF and 1.59 to $1.66 \mathrm{WC}$ respectively (Table 3 ).

In the same vein, the $\mathrm{LC}_{50}$ at $95 \%$ confidence limits of four weeks old tadpoles exposed to WSF, WIF and WC were determined as $1.62 \pm 0.37$ for WSF, $1.65 \pm 0.42$ for WIF and $1.63 \pm 0.32$ for WC 1.58 to 1.65 for WIF, 1.62 to 1.69 for WIF and 1.59 to 1.66 for WC (Table 3). 
Table 7: Shows Mean $\mathrm{LC}_{50}$ at $95 \%$ confidence limits of 3- and 4-weeks old tadpoles of $\mathrm{H}$. occipitalis exposed to

21 | Mowang et al., 2020

$\begin{array}{lll}\mathrm{LC}_{50} \pm 95 \% \mathrm{C} . \mathrm{L} & \begin{array}{l}\text { Lower limit confidence } \\ \text { limit }\end{array} & \begin{array}{l}\text { Upper limit confidence } \\ \text { limit }\end{array} \\ (\mathrm{ppm}) & & \end{array}$

Three Weeks Old Tadpoles

$\begin{array}{llll}\text { WSF } & 1.60 \pm 0.32 & 1.57 & 1.64 \\ \text { WIF } & 1.65 \pm 0.39 & 1.62 & 1.68 \\ \text { WC } & 1.63 \pm 0.28 & 1.59 & 1.66\end{array}$

Four Weeks Old Tadpoles

$\begin{array}{llll}\text { WSF } & 1.62 \pm 0.37 & 1.58 & 1.65 \\ \text { WIF } & 1.65 \pm 0.42 & 1.62 & 1.69 \\ \text { WC } & 1.63 \pm 0.32 & 1.59 & 1.66\end{array}$

WSF-Water Soluble Fraction, WIF-Water Insoluble Fraction, WC-Whole Crude, LC-Lethal concentration,

C.L- Confidence Limits

PROBIT ANALYSIS OF MORTALITY RATES OF THREE WEEKS AND FOUR WEEKS OLD TADPOLES OF $\boldsymbol{H}$. OCCIPITALIS EXPOSED TO CRUDE PETROLEUM FRACTIONS.

Results of probit analysis showed that as the concentrations of toxicants (WSF, WIF and WC) increased there was a corresponding increase in mortalities. The mortality data was subjected to probit transformation using statistical package for social sciences (SPSS 18.0) and the significance of the slope tested using analysis of variance (ANOVA) and Duncan Multiple range test. This revealed no significant differences ( $p>0.05$ ) between 3- and 4-weeks old tadpoles exposed to different crude fractions (WSF, WIF and WC).

The $96 \mathrm{LC}_{50}$ probit analysis of three weeks old tadpoles of H.occipitalis in WSF was determined at log concentration 1.60, 1.65 in WIF and 1.62 in WC respectively (Figure 2). In the same vein, the probit level $\mathrm{LC}_{50}$ of the four weeks old tadpoles in WSF was 1.61, 1.65 in WIF and 1.62 in WC respectively (Figure 3). 


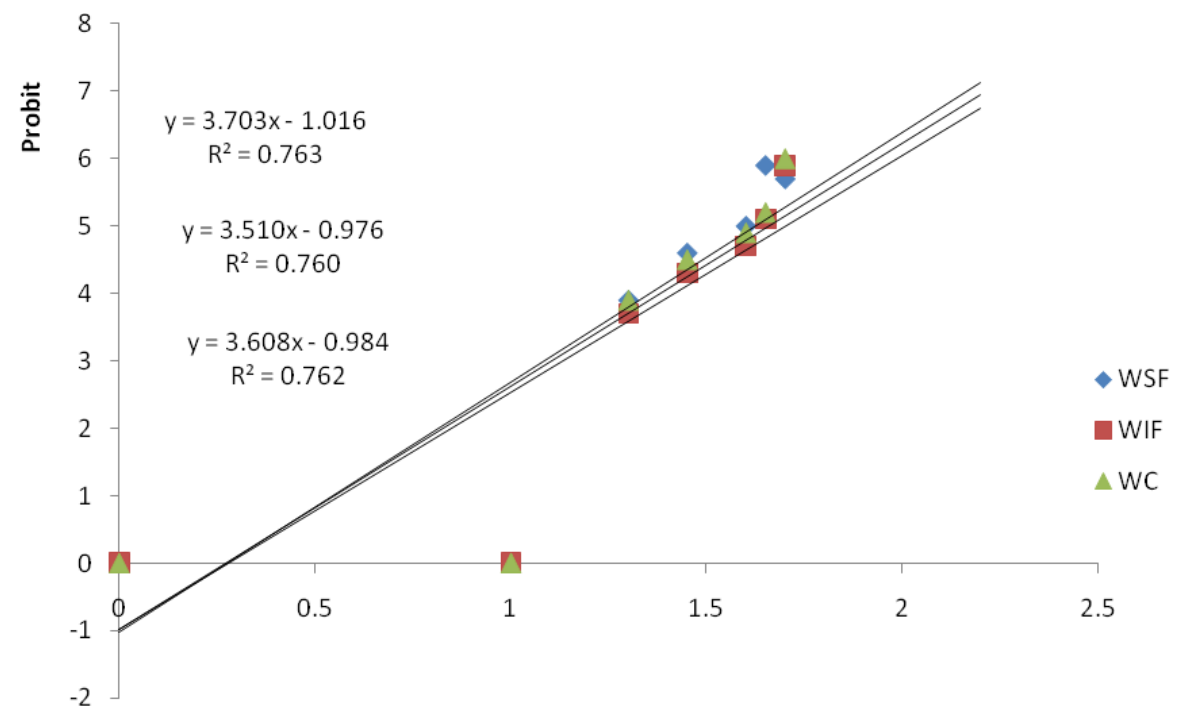

Log of Concentration (ppm)

Figure 2: The relationship between percentage mortality and concentration of toxicants on the three weeks old tadpoles of Hoplobactrachus occipitalis (Crowned bullfrog).

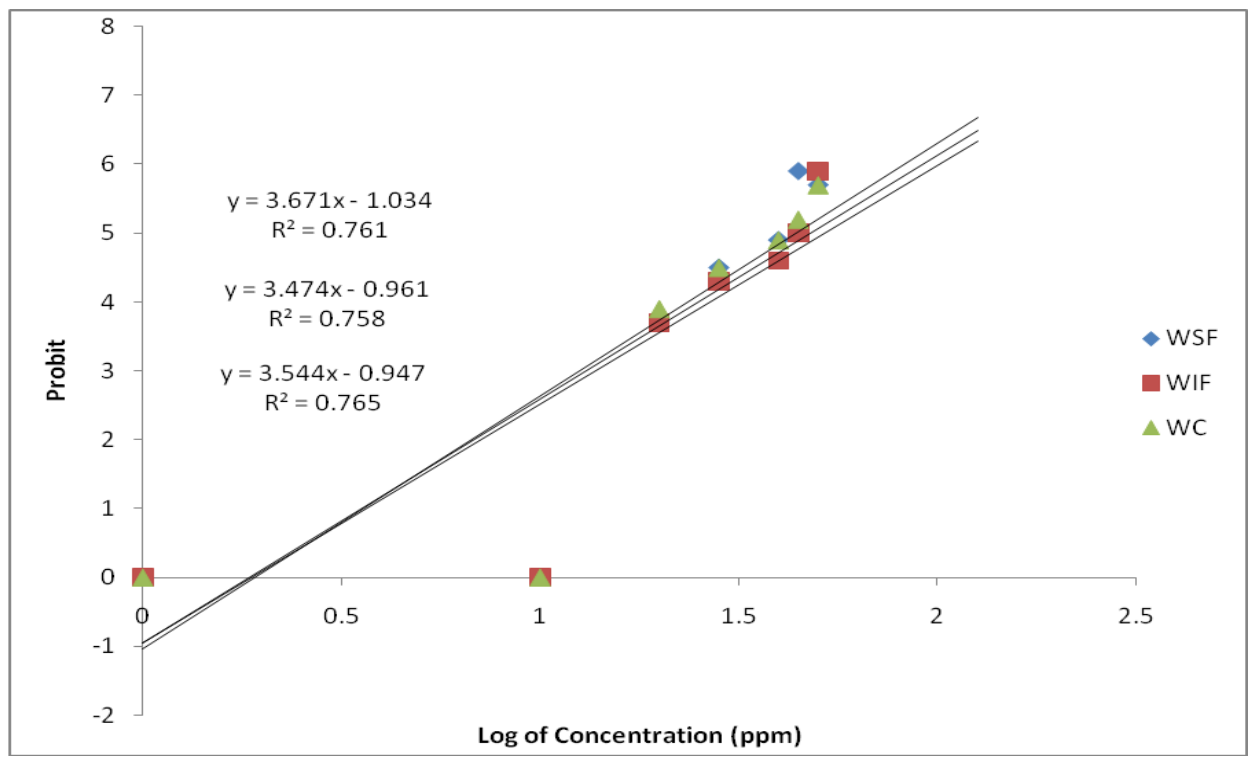

Figure 3: The relationship between percentage mortality and concentration of toxicants on the four weeks old tadpoles of Hoplobactrachus occipitalis (Crowned bullfrog). 


\section{DISCUSSION}

\section{PERCENTAGE MORTALITIES OF THREE WEEKS AND FOUR WEEKS OLD TADPOLES OF H. OCCIPITALIS.}

In three weeks old tadpoles, the percentage mortalities after $96 \mathrm{~h}$ of exposure ranged from $0-75 \%$ in WSF, $0-65 \%$ in WIF and $0-70 \%$ in WC respectively. In four weeks old tadpoles exposed to different fractions of crude petroleum, the percentage mortalities recorded in the fractions ranged from $0-75 \%$ in WSF, $0-65 \%$ in WIF and $0-75 \%$ in WC. The percentage mortalities of three weeks old tadpoles and four weeks old tadpoles of H. occipitalis exposed to WSF of crude were $(75 \%)$ in the two stages While the percentage mortalities of three weeks old tadpoles exposed to $1.69 \mathrm{ppm}$ of crude were different (75\% in WSF, 65\% in WIF and 70\% in WC).In the four weeks old tadpoles, the percentage mortalities after 96hrs of exposure were the same for WSF and WC, that is (75\%).There were no significant differences $(\mathrm{P}>0.05)$ in percentage mortalities of three weeks old tadpoles and four weeks old tadpoles exposed to WIF, that is $65 \%$ in both stages. The mortality rates in all the fractions (WSF, WIF and WC) were more than $50 \%$. Generally, there were no significant differences $(P>0.05)$ in mortalities between the three- and four-weeks old tadpoles exposed to different fractions of crude petroleum. This disagrees with the findings that one- and two-weeks old tadpoles of $H$. occipitalis exposed to different fractions of crude petroleum recorded a significant difference (P < 0.05) in mortalities (Mowang et al., 2015). This also disagrees with the assertion of Stene and Lonning (1984) that, it seems like eggs are more resistant towards hydrocarbon pollution than larvae; and agrees with the assertion that yolk sac larvae represent the most sensitive early life stage to hydrocarbon exposure (Anderson., 1971; Akaisha, et al., 2004).

\section{MANIFESTATION AND SURVIVAL TIME OF THREE- AND FOUR-WEEKS OLD TADPOLES EXPOSED TO DIFFERENT FRACTIONS OF CRUDE PETROLEUM.}

There were no significant differences $(\mathrm{P}>0.05)$ in the manifestation and survival times of three weeks and four weeks old tadpoles exposed to different fractions of crude petroleum. The manifestation and survival time of three and four weeks old tadpoles exposed to fractions of crude were all concentration dependent, as we observed higher manifestation/survival time in lower concentrations and lower manifestation/survival time in higher concentrations as reported in the previous section of this work that aquatic life expose to low concentration of toxicants do not reach the threshold stage of exhaustion rather they quickly become adapted to the stressor. This is in line with Ndome et al., (2013) who found that the manifestation and survival times of fingerlings of Clarias gariepinus in Omo and Ariel were decreasing with increase in concentrations of toxicants. Fryer (1977) had earlier reported that all animals lie within a tolerable zone of toxicants which lies below the threshold. Omoriegie et al., (2002) studied the effects of water-soluble fractions of crude on the growth of Oreochromis niloticus and reported that control fish exposed to the lowest concentrations of toxicant fed normally throughout the study. He also observed that exposure to higher concentrations of the toxicants affect the feeding behavior of Oreochromis niloticus.

The $96 \mathrm{~h} \mathrm{LC}_{50}$ of any toxicant is the dose or concentration which kills $50 \%$ of the stocked organisms at the end of the experimental period of $96 \mathrm{~h}$. The $\mathrm{LC}_{50}$ probit levels are points were $50 \%$ of the organisms would be killed at the end of the $96 \mathrm{~h}$ of the toxicants finding their ways into the habitats of the organisms. The three- and four-weeks old tadpoles recorded no significant differences $(\mathrm{P}>0.05)$ between fractions. (Samabaswa and Rao, 1985; Akpan et al., 1999; Udo et al., 2006; APHA, AWWA \& WPCF, 1989; APHA, 1989). The 96h LC 50 is known to vary from 
toxicant to toxicant (APHA, 1998; Samabaswa and Rao, 1985; Ayotunde et al., 2011) and from concentration to concentration of the toxicant.

\section{CONCLUSION}

The mortalities increased with increase in concentration of toxicants. The death of organisms in WIF was not caused by dissolved petroleum rather by carbon layer on the surface of the media which prevented oxygen penetration thus causing suffocation and death. The present study has shown that the concern for the aquatic environment with regards to the introduction of anthropogenic substances especially crude oil is not exaggerated. The danger is real and no effort should be spared to ensure that the damaging effects of oil on the ecosystem especially on their resident biota, particularly in the Niger Delta, one of the breeding grounds and natural habitat of H. occipitalis is removed completely or reduced. This study has also demonstrated that the WSF, WIF and WC of crude oil have a highly significant effect on the growth and development of eggs and tadpoles of $H$. occipitalis and that the early stages of $H$. occipitalis can serve as a bio-indicator of crude oil pollution in the Niger Delta. This study therefore advocates that Oil companies should adhere to the current WHO / FEPA regulatory limits of $0.2 \mathrm{mg} / \mathrm{l}$ to $14.0 \mathrm{mg} / \mathrm{l}$ for $\mathrm{C}_{5}-\mathrm{C}_{22}$ hydrocarbons to ensure the survival of its vital ecological niche.

\section{RECOMMENDATION}

Further studies to ascertain the tolerance limits of other local African species of frogs to environmental pollution should be conducted and particular attention should be given to crude oil production process aimed at minimizing the environmental hazards due to oil spillage. These studies should also focus on possible effects and influence on later life (adult stages) of oil exposed H. occipitalis eggs and tadpoles. Environmental impact assessment (EIA) should be encouraged for effective monitoring and controls of amphibians.

\section{REFERENCES}

Anderson, J. D., Hassinger, D. D. and Dalrymple G. H. (1971). Natural mortality of eggs and larvae of Ambystoma tigrinum. Ecology 52: 1107-1112.

Akaisha, F. M., De Assis, H.C., Jaakobi, S.C., Eras-stofella, D. R., St. Jean, , S. C., Lima, E. F., Wagner, A. L. Scofield, A. L. AND Ribeiro, C. A. (2004). Morphological and neurotoxicological findings in tropical freshwater fish (Astyanax sp) after waterborne and acute exposure to water soluble fraction of crude oil. Archives Environmental Contamination Toxicology., 46:244-253.

Akpan, E. R., Ekanem, S.B., Odaro, J. A. (1999). Toxicity of crude oil to freshwater algae. African Journal Fisheries Aquaculture, 1:56-61.

APHA (American Public Health Association) (1989). Standard method for examination of waste water. Clesan, L. S., A. A. Greenberg and R. E. Russel, $17^{\text {th }}$ Edition, 314pp.

APHA, AWWA and WPCF (1989). Standard method for the examination of water and waste waters $20^{\text {th }}$ ed.American Public Health Association, Washington, DC, pp 423-427. 
Ayotunde, E. O. Offem, B. O. and Bekah, A.F. (2011). Toxicity of Carica papaya Linn: Haematological and piscidal effect on adult catfish (Clarias gariepinus). Journal of Fisheries and Aquatic Science 6(3):291-308.

Blaustein, A. R., Romansic, J. M., Klesecker, J. M. and Hatch, A. C. (2003). Ultraviolet radiation, toxic chemicals and amphibian population declines. Diversity and distributions. 9:1791-1795.

Burkhart, J and Snodgrass. (2002). Metal levels in Southern Leopard Frogs from the Savannah River Site: Location and body compartment effects. Environmental Reseach Section A. 86: 157 - 166.

Dede, E. B. and Kagbo, H. D. (2001). Aqua toxicological effects of water-soluble fraction (WSF) of diesel fuel on Oreochromis niloticus fingerlings. Journal of Applied Science and Environmental Management, 5(1): 93-96.

Enyamremu, G. E., Osagie, S. E. Omoregie and C. O. Omofoma (2007). Alterations in glutathione lipid peroxidation of tadpoles (Xenopus laevis) exposed to bonny light crude oil and its fractions. Ecotoxicology and Environment. 234:1-11.

Fryer, J. D. (1977). Weed control handbook vol.1. Edited by make peace, London $\quad$ pp.384-389.

Ezemonye L. and Ewuneku (2005). Evaluation of acute toxicity of Cadmium and Lead to amphibian tadpoles

(Toad: Bufo maculates and Frog: Ptychadena bibroni. National Academic of Science. 99:4 - 6.

Mahaney, P. A. (1994). Effects of freshwater petroleum contamination on amphibian hatching and metamorphosis. Environmental Toxicology and Chemistry. 13: 259-265.

Mgbeahuru, J. E. (2002). The influence of $\mathrm{pH}$ on the toxicity of domestic detergents against tadpoles of Rana rana and fingerlings of Tilapia niloticus. M.Sc thesis University of Benin, Nigeria 67pp.

Mowang, D. A., Ajang R. O., Ndome C. B., Effanga E. O. (2015). Acute toxicity of water soluble, water insoluble fractions and whole crude (Bonny light) on the growth and development of one- and two-weeks old tadpoles of the Crowned Bullfrog (Hoplobatrachus occipitalis) in Calabar, Nigeria. Journal of Biopesticides and Environment. 2(1-2): 36-46.

Ndome, C.B., Mowang D.A. and Tonkumo T. A. (2013). Comparative acute toxicity of local detergents (omo and ariel) on fingerlings of the Clarias gariepinus 9 x Heterobranchus longifilis ${ }^{\top}$ hybrid. AACL Bioflux 6 (4):415 -420 .

Negbenebor, I. M. (2002). The effect of laundry effluent on selected bio indicators of pollution (Tadpoles of Bufo regularis, fingerlings of Heteroclarias species and larvae of Chinonomus travenlensis). B.Sc dissertation, University of Benin, Nigeria 48pp.

Omoregie, E. and Ufodike, B. C. (20002). Effects of water soluble fraction of crude oil or growth of the Nile Tilapia (Oreochromis niloticus)(L). Bulletin of environmental contamination and toxicology. 64:601-605.

Relyea, R.A. (2004). The impact of insecticides and herbicides on the biodiversity and productivity of aquatic communities. Ecological Applications: 15(2): 618-627

Relyea, R.A. (2005). The lethal impact of Roundup on aquatic and terrestrial amphibians. Ecological Applications 15(4):1118-1124. 
Samabaswa, K.S. and Rao, K. R. (1985). Toxicity of Elsan to the Indian snakehead (Chana punctatus). Indian Journal of Fisheies. 3:153-159.

Stene, A and Lonning, S. (1984). Effects of 2-Methylnaphtalene on eggs and larvae of six marine fish species. Sarsia. 69:199-203.

Udo, P. J., Ekanem, A. P. and Eze, E. E. (2006). Toxicity of crude oil to early life stages of Heterobranchus longifilis (Cruveier and Valiennces) Pisces: Bagridae). Tropical Environmental Research. 1:450-459. 